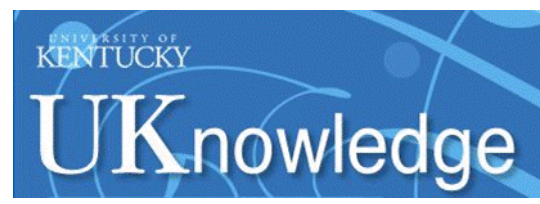

University of Kentucky

UKnowledge

Educational, School, and Counseling

Psychology Faculty Publications

Educational, School, and Counseling

Psychology

$12-1-2004$

\title{
The Communication Challenge of Standards-Based Reporting
}

Thomas R. Guskey

University of Kentucky, GUSKEY@UKY.EDU

Follow this and additional works at: https://uknowledge.uky.edu/edp_facpub

Part of the Educational Assessment, Evaluation, and Research Commons

Right click to open a feedback form in a new tab to let us know how this document benefits you.

\section{Repository Citation}

Guskey, Thomas R., "The Communication Challenge of Standards-Based Reporting" (2004). Educational, School, and Counseling Psychology Faculty Publications. 31.

https://uknowledge.uky.edu/edp_facpub/31

This Article is brought to you for free and open access by the Educational, School, and Counseling Psychology at UKnowledge. It has been accepted for inclusion in Educational, School, and Counseling Psychology Faculty Publications by an authorized administrator of UKnowledge. For more information, please contact UKnowledge@lsv.uky.edu. 


\section{The Communication Challenge of Standards-Based Reporting \\ Digital Object Identifier (DOI) \\ https://doi.org/10.1177/003172170408600419}

\section{Notes/Citation Information}

Published in Phi Delta Kappan, v. 86, issue 4, p. 326-329.

(c) 2004, Thomas R. Guskey

The copyright holder has granted the permission for posting the article here. 


\section{The Communication Challenge Of Standards-Based Reporting}

\section{As traditional reporting systems based on letter grades are replaced by standards-based reporting systems, parents are often left wondering how}

their child is doing in school. Mr. Guskey offers some suggestions for overcoming this communication challenge.

\section{BY THOMAS R. GUSKEY}

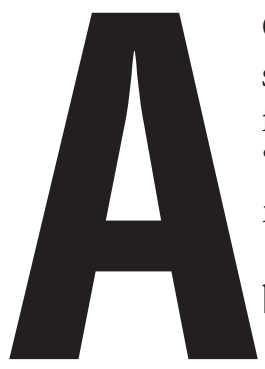

CLASSIC comic from the "Hi \& Lois" strip shows their son arriving home from school and proudly announcing, "My teacher gave me a 'Super' on my report."

"Wow!" exclaims Lois. "Is that the best you can get?"

"No," he replies. "'Stupendous,' 'Outrageous,' and 'Magnificent' are all better. 'Super' is just okay."

Like all good humor, this comic strip strikes a familiar note with many readers, especially the parents of school-age children. It also highlights one of the greatest challenges educators face today: describing students' level of academic performance in meaningful ways to parents and others. ${ }^{1}$

Moving away from traditional reporting systems based on letter grades and toward standards-based reporting systems means that we must articulate clearly what we expect students to learn and be able to do. That curriculum challenge is generally met through the development of specific content and performance standards. While meeting this challenge has been difficult and the quality of the work wide-ranging, most states and school districts today have curricula that are based on standards. The communication challenge of issuing progress reports and report cards that describe students' performance with regard to those standards,

THOMAS R. GUSKEY is a professor in the College of Education, University of Kentucky, Lexington. (C) 2004, Thomas R. Guskey. however, remains before us. It's also proving to be a more difficult challenge than most educators ever anticipated.

\section{STANDARDS-BASED REPORT CARDS}

Developing a standards-based report card is a multistep process. First, the major learning goals or standards must be identified, and the specific performance cri-

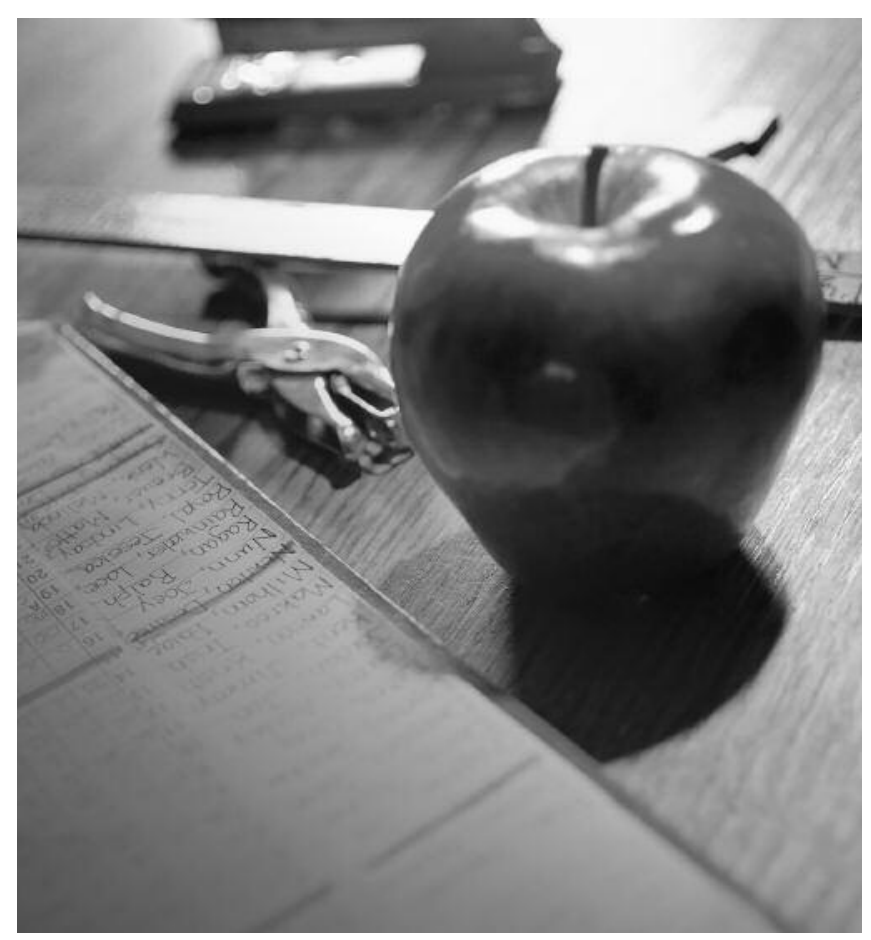


teria for demonstrating mastery of those goals or standards have to be set. Next, graduated levels of performance — or benchmarks — for achieving each goal or standard must be established. This effort typically requires determining three or four identifiable steps in students' progress toward mastery of each standard. In addition, meaningful labels need to be attached to these levels or steps in order to describe students' progress to their parents, to other interested parties, and to the students themselves. This is where the communication challenge gets particularly tricky.

To discover what terminology educators currently use to convey different levels of progress in student learning, I recently collected the labels from standardsbased report cards obtained from a non-random sample of school districts throughout the U.S. and Canada. I also gathered the labels used to denote different levels of student performance in a number of state assessment programs and several well-known standardized assessment programs. Two colleagues and I then grouped these labels into general categories based on our judgments of what aspects of performance they were intended to describe. (See Table 1.) While most of these judgments were easy enough, deciding whether a label pertained to a level of "Understanding/Quality" or a level of "Mastery/Proficiency" proved particularly troublesome and remains open to discussion.

Next we shared these labels with parents of schoolage children in structured focus groups. We asked the parents to identify which labels made sense and which ones did not. Their responses were amazingly consistent, highly informative, and, in some cases, quite surprising.

\section{PARENTS' INTERPRETATIONS}

We found that parents generally interpreted the labels according to their personal experiences with grading and reporting. And since parents' experiences with grades tend to be restricted to letter grades, most parents immediately translated each label into a letter grade. So, for example, "Advanced" means "A," "Proficient" means "B," and so on. Regardless of the labels actually used, the meaning parents took away from them was based on what they be-

\section{TABLE 1.}

Ineffective lieved they understood best, and, for most parents, that was letter grades.

By and large parents also interpreted the labels from a norm-referenced perspective. Again, probably as a result of their personal experiences in schools where grades were based on each student's relative standing among classmates, parents interpreted the labels similarly. So for many parents, "Basic" and "Intermediate" imply "average" or "in the middle of the class."

After explaining to parents that these labels were designed to communicate a student's learning progress with regard to specific learning goals or standards, rather than to designate a student's standing among classmates, we asked parents to identify the labels that seemed clearer or more meaningful. Most of the labels received mixed responses, with no particular set being clearly preferred. However, certain labels were singled out by parents as confusing or meaningless.

Parents were especially baffled by the labels "PreEmergent" and "Emerging." Several remarked jokingly that "Emerging" conveyed images of "a slimy creature coming out of a swamp." When we indicated that "Emerging" generally implies "Beginning," they responded, "If you mean 'Beginning,' why not just say 'Beginning?"

Another label parents found puzzling was "Exceeds Standard." Labels such as "Advanced," "Exemplary," "Distinguished," and "Outstanding" all seemed to have

\section{Indicators of Student Performance}

1. Levels of Understanding/Quality

Modest Beginning Novice Unsatisfactory

Intermediate Progressing Apprentice Needs Improvement

Proficient Adequate Proficient Satisfactory

Superior Exemplary Distinguished Outstanding

\section{Levels of Mastery/Proficiency}

$\begin{array}{llll}\text { Below Basic } & \text { Below Standard } & \text { Pre-Emergent } & \text { Incomplete } \\ \text { Basic } & \text { Approaching Standard } & \text { Emerging } & \text { Limited } \\ \text { Proficient } & \text { Meets Standard } & \text { Acquiring } & \text { Partial } \\ \text { Advanced } & \text { Exceeds Standard } & \text { Extending } & \text { Thorough }\end{array}$

\section{Frequency of Display}

Rarely Never

Occasionally Seldom

Frequently Usually

Consistently Always

4. Degree of Effectiveness

Poor

Moderately Effective

Highly Effective

Acceptable

Excellent

\section{Evidence of Accomplishment}

Little or No Evidence

Partial Evidence

Sufficient Evidence

Extensive Evidence 
clearer meaning. Parents understood how specific expectations or criteria might be associated with these levels. But to many parents, "Exceeds Standard" was especially vague and imprecise. Several interpreted it as meaning something "more than what's expected," but they were unsure just what that might be.

\section{MEETING THE COMMUNICATION CHALLENGE}

To improve the usefulness and communicative value of standards-based report cards, we need to ensure that parents and others understand the information they include. We must also acknowledge that, if parents don't understand the information in the report card, it's not their fault. As communicators, it is our responsibility to make sure that our message is clear and comprehensible to those for whom it is intended. This is the essence of the communication challenge involved in developing a standards-based report card.

Therefore, in describing different levels of students' performance with regard to learning goals or standards, we must choose labels that are expressive, precise, and meaningful. The following four guidelines should help in that effort.

1. Avoid comparative language. Because parents so often interpret grades in terms of norm-referenced comparisons, in which a child's performance is judged relative to that of his or her classmates, adjusting to a standards-based, criterion-referenced system is particularly difficult. The transition is made all the more frustrating when educators use such comparative labels as "Below Average," "Average," and "Superior." The labels we use should always relate to clearly stated performance indicators that communicate where students stand in reference to specific expectations for their learning. This helps parents change their perspective from "How is my child doing compared to other students in the class?" to "How is my child doing with regard to the learning expectations for this level?"

2. Provide examples based on student work. One of the best ways to promote understanding and to facilitate parents' transition from norm-referenced comparisons to standards-based reporting is to provide clear examples of student work at the various performance levels. Such examples enhance parents' knowledge of teachers' expectations. They also allow parents to become more discerning judges of their child's performance and then to better assist their child in making progress. This requires that school leaders provide time for teachers to engage in conversations about what is meant by "Proficient" and what examples of "Proficient" student work look like.

3. Distinguish between "Levels of Understanding" and "Frequency of Display." Parents get confused when educators use indicators that confound what students are able to do with how often they do it. The first implies "quality" to parents, while the second appears to signify "quantity" or "rate of occurrence." While "Frequency of Display" labels such as "Occasionally," "Frequently," and "Consistently" work well when describing students' work habits, study skills, or behavior in school, they often fall short when trying to explain to parents what students have learned and are able to do.

4. Be consistent. One reason so many parents translate labels into letter grades is that it provides a common basis for understanding and interpretation. This is particularly true in schools where one set of labels is used on the elementary report card, another set on the secondary report card, another set for state assessment results, and still another set for standardized assessment reports. No wonder parents who face this mishmash ask, "Are 'Adequate' and 'Satisfactory' the same as 'Proficient'? Are they all equivalent to a 'B'?' Achieving consistency may prove difficult in schools bound to the use of labels incorporated in their state's assessment system. Still, by reducing the number of labels with which parents must contend, educators can facilitate parents' understanding and encourage greater parent involvement in education.

Our knowledge of effective grading and reporting has grown tremendously in recent years, although little of that knowledge seems to be finding its way in- 
to practice. ${ }^{2}$ One theme that has emerged from this fund of new knowledge is that grading and reporting are less exercises in quantifying achievement than they are challenges in effective communication. ${ }^{3}$ Deciding what labels to use in describing students' level of performance with regard to standards is an essential first step in meeting that communication challenge.

Labels must be chosen to convey honest, meaningful, and useful information to parents and others in order to facilitate their understanding of educators' expectations for student learning. When parents and others recognize the intent of a standards-based report card and can make sense of the information it includes, they are better able to work with educators as partners in school improvement. ${ }^{4}$ Perhaps most important, a standards-based report card that uses clear and understand- able labels helps break down the barriers between home and school and provides a basis for effective collaboration in efforts to help every student learn well.

1. Thomas R. Guskey, "Helping Standards Make the Grade," Educational Leadership, September 2001, pp. 20-27.

2. See, for example, Susan M. Brookhart, Grading (Upper Saddle River, N.J.: Merrill/Prentice-Hall, 2004); Thomas R. Guskey and Jane M. Bailey, Developing Grading and Reporting Systems for Student Learning (Thousand Oaks, Calif:: Corwin Press, 2001); Thomas H. Haladyna, A Complete Guide to Student Grading (Boston: Allyn \& Bacon, 1999); and Robert J. Marzano, Transforming Classroom Grading (Alexandria, Va.: Association for Supervision and Curriculum Development, 2000).

3. Ken O'Connor, How to Grade for Learning: Linking Grades to Standards, 2nd ed. (Arlington Heights, Ill.: SkyLight, 2002); and Richard J. Stiggins, Student-Involved Classroom Assessment, 3rd ed. (Upper Saddle River, N.J.: Merrill/Prentice-Hall, 2001), pp. 409-65.

4. Thomas R. Guskey, How's My Kid Doing? A Parents' Guide to Grades, Marks, and Report Cards (San Francisco: Jossey-Bass, 2002). 